\title{
APPLICATION OF ANTIBROWNING AND FIRMNESS SUPPORTING COMPOUNDS TO MAINTAIN THE QUALITY OF FRESH-CUT GUAVA
}

\author{
(Received 22-11-2017) \\ By \\ E. H. Khedr and M. R. Ali* \\ Department of Pomology and *Department of Food Science, Faculty of Agriculture, \\ Cairo University, Egypt
}

\begin{abstract}
The present study aimed to extend fresh-cut guava life and retain quality using safe compounds without affecting quality or palatability. Different concentrations of ascorbic acid, citric acid and calcium lactate were used before storage at $5^{\circ} \mathrm{C}$ for 12 days in two successive seasons. It has been found that citric acid at $2 \%$ was the most effective in the case of fresh-cut guava compared to untreated ones in different traits under study in terms of general appearance, total soluble solids/acid ratio, colour changes, browning index and decay percentage. Citric acid and ascorbic acid treatments showed significant impacts on fresh-cut guava content of total phenols and ascorbic acid. While, calcium lactate at $2 \%$ showed the least significant values of weight loss and the highest significant firmness compared with the control.
\end{abstract}

Key words: Antioxidants, ascorbic, citric, calcium lactate, cold storage, guava slices.

\section{INTRODUCTION}

Guava (Psidium guajava $\mathrm{L}$.) is a popular fruit and is considered a source of abundant ascorbic acid and high nutritional value. Most guava varieties are usually classified as climacteric fruits (Brown and Wills, 1983), which are characterized by high respiration rate and rapid deterioration. There is growing consumers demand for fresh-cut products, and there are special sections of those products in most hypermarkets. Fresh-cut fruits are very desirable and have great market potential, as they are easy and fast to eat. Fresh-cut products should be in a good appearance and palatability, free of defects and have appropriate shelf life period.

Fresh-cut products are extremely perishable owing to the absence of the outer protective layer of their tissue. The cutting process increases the injured tissues, which are very sensitive to browning and pathogenic diseases, thus promoting rapid deterioration (Alley et al., 1996). Watada and Ling (1999) reported that fresh-cut fruits are very perishable due to cut surfaces and exposed tissues and lack of protective skin.

Amiot et al. (1995) reported that browning of fresh-cut pieces is instigated by polyphenol oxidase effect on phenolic compounds released during the practice of cutting, disorders resultant from cutting can be reduced by the use of sharp cutting implements, enzymatic browning inhibitors, modified atmospheres and low temperatures. Gil et al. (2006) reported that the response of fresh cut fruits is different compared with full fruits in response to the same treatments.

Although there is a large amount of ascorbic acid in guava fruit compared to other fruits, it is not enough to stop the deterioration and browning especially after cutting and storage prolongation (Abd El-Moneim et al., 2015).

Calcium as a constituent of the cell wall plays an important role in establishing cross-links, which affects strength and regarded as the last barrier before cell separation due to cutting practice (Fry, 2004). Calcium treatments used for tissue firmness have also been reported to reduce browning (Drake and Spayed, 1983). Varela et al. (2007) proposed the valuable use of calcium treatments in fresh-cut apples stored for 16 days at $8-10^{\circ} \mathrm{C}$.

Irene and Diane (2000) reported that calcium lactate did not cause undesirable bitterness to fresh-cut fruits compared with calcium chloride that commonly used as a source of calcium in postharvest treatments. Also, Raheem et al. (2013) and Patchimaporn et al. (2014) reported that pretreatment of calcium lactate could be an 
alternative to calcium chloride in fruits as it improved quality.

Ascorbic acid is frequently used as enzymatic browning inhibitor as it chelates copper ions, reduces o-quinones and acts as a polyphenol oxidase inhibitor (Lozano-De-Gonzalez et al., 1993). Citric acid and other acidifying compounds are also used as enzymatic browning inhibitors in vegetables and fruits in combination with ascorbic acid. Santerre et al. (1988) found that citric acid inhibited enzymatic browning to a similar degree in apple slices with ascorbic acid.

Ascorbic and citric acids are effective methods to reduce oxidation and deterioration in fruits. Dipping fruit slices in ascorbic and citric acids $(0.2-10 \mathrm{~g} / \mathrm{l})$ solutions for $5 \mathrm{~min}$. had an impact on polyphenol oxidase activity, colour changes and deterioration in fruits (Pizocaro et al., 1993). Also, Gil et al. (2006) found that ascorbic acid treatment at $2 \%$ was effective in deferment the browning of apple slices.

The main objectives of the current study were to investigate the influence of ascorbic acid, citric acid and calcium lactate on fresh-cut guava to extend the shelf life and determine the acceptability and quality characteristics of treated fresh-cut guava fruits.

\section{MATERIALS AND METHODS}

Fruits of guava cv. Baladi were harvested manually at the commercial maturity stage (Kader, 1999 and Sing and Pal, 2008) from a private orchard in El- Beheira Governorate, Egypt in 2014 and 2015 seasons.

Fruits were almost similar in size and skin colour, and free of obvious pathological defects and mechanical injuries. Fruits were washed by tap water, sliced (1 $\mathrm{cm}$ thickness) and the central seeds portion of the fruits were removed according to the procedure of Durigan et al. (2005), then dipped in one of the following solutions; 1 or $2 \%$ ascorbic acid, 1 or $2 \%$ citric acid, 1 or $2 \%$ calcium lactate, and distilled water (control) for $5 \mathrm{~min}$., then the treated slices were left to dry at room temperature. Slices were packed in plastic packages (average 250 g/package) and stored at $5^{\circ} \mathrm{C}, 90-95 \%$ relative humidity for 12 days. Nine pieces from each replicate of each treatment were sampled for analysis after 3 days intervals.

The influence of cutting and cold storage on the quality indices and chemical characteristics of fresh-cut guava were evaluated.

Any signs of spoilage during storage were scored and discarded, decay percentage was calculated as the number of discarded slices / total number of slices $\times 100$.

General appearance of slices was observed visually using the described procedure by Mitcham et al. (2003); on a scale from one to nine with $1=$ unacceptable, $3=$ poor, $5=$ fair, $7=$ good, and $9=$ excellent.

Instrumental slice colour was measured in the CIE L ${ }^{*} a^{*} b^{*}$ on two opposed sides of each slice objectively. Each measurement was taken at three locations for each slice, using a Minolta CR-400 chroma meter (Minolta, Osaka, Japan) according to McGuire (1992).

Browning index was measured using the formula mentioned by Ruangchakpet and Sajjaanantakul (2007) as following; browning index $(\mathrm{BI})=(100(\mathrm{x}-0.31)) / 0.17$, where $\mathrm{x}=$ $\left(\mathrm{a}^{*}+1.75 \mathrm{~L}^{*}\right) /\left(5.645 \mathrm{~L}^{*}+\mathrm{a}^{*}-0.3012 \mathrm{~b}^{*}\right)$.

Weight loss percentage was calculated using the following equation; (package initial weight package weight at each sampling date) / package initial weight $\times 100$.

Guava firmness was determined according to Mitcham et al. (2003) using a fruit pressure tester, data were presented as $\mathrm{lb} / \mathrm{inch}^{2}$.

TSS / Acid ratio was calculated via estimating total soluble solids and titratable acidity. Total soluble solid percentage was assessed by using a digital refractometer (model Palette, ATAGO), using drops of the fruit juice. Total acidity was measured using the titration method by $10 \mathrm{ml}$ of the extracted juice against $0.1 \mathrm{~N}$ of $\mathrm{NaOH}$, using Phenolphthalein indicator (A.O.A.C. 1980), and mentioned as percentage of citric acid.

Total phenols as mg gallic acid per $100 \mathrm{~g}$ fresh weight were determined colourmetrically using Folin Denis reaction method at $765 \mathrm{~nm}$ according to A.O.A.C. (2012).

Ascorbic acid was determined using titration method by 2,6 dicholorophenol-indophenol solution. Results were expressed as mg ascorbic acid per 100 g FW (Mazumdar and Majumder, 2003).

A completely randomized block design was followed, the treatment means were estimated using the method of LSD at the 5\% level of significance (Snedecor and Cochran, 1989).

\section{RESULTS AND DISCUSSION \\ 3.1. Decay percentage}

Data in Fig. (1) present the effect of ascorbic acid, citric acid and calcium lactate treatments on decay percentage in both seasons. Decay percentage increased gradually during storage 
especially after 9 days of storage at $5^{\circ} \mathrm{C}$. Citric acid at $2 \%$ recorded the lowest significant values compared with the control in 2014 and 2015 seasons.

Both citric acid treatments showed the lowest percentages of decay after 12 days of storage at $5^{\circ} \mathrm{C}$, whereas $2 \%$ citric acid exhibited the least percentage of decay in the second season compared with the control that showed the highest rates as 66.67 and $61.11 \%$ in the first and the second season respectively.

The shelf or marketing life of a produce can be defined as how long the produce will be agreeable for the consumers (Labuza and Schmidl, 1988). Damage of external tissues during preparative stage of cutting process, leaks cytoplasm and provides a potentially richer source of nutrients for the microorganisms. In addition, high water contents induce microbial growth in fresh cut fruits and vegetables (Shah and Nath, 2006).

Citric acid is an anti-browning agent that prevents polyphenol oxidase activity by decreasing $\mathrm{pH}$ and binding the copper in an active site of this enzyme to form a defused complex (Martinez and Whitaker, 1995) which reduces deterioration and make them less susceptible to pathogens. In this way, Gonzalez-

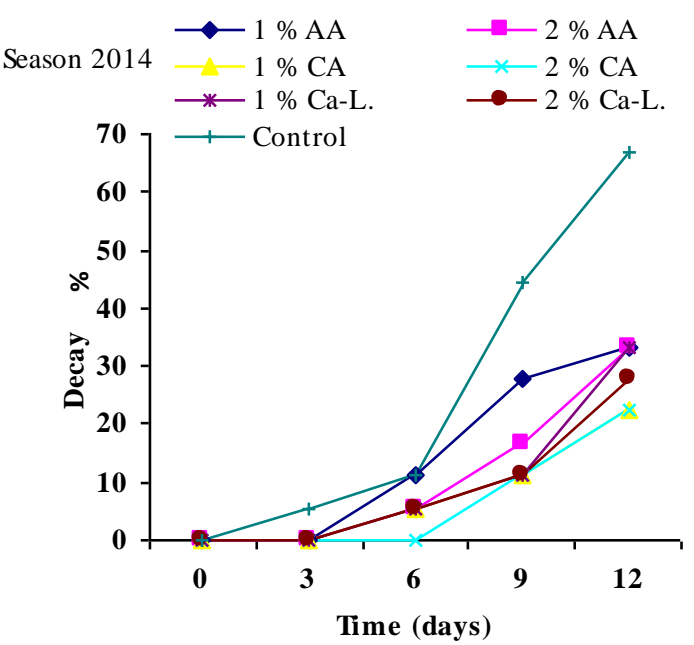

This decrement appeared clearly in the ninth day of storage at $5^{\circ} \mathrm{C}$. Different treatments maintained slices appearance compared with untreated ones. Citric acid at $2 \%$ was the most acceptable compared with the control that was fair after 6 days of cold storage in both seasons.

Fresh-cut fruits loss its attractive appearance rapidly because of colour changes and soft tissues (Alley et al., 1996). The obtained findings declare that citric acid was effective in maintaining good appearance and freshness, which may be explained as a limiting factor of discolouration (Sams, 1999). Also, citric acid treatments did not exhibit any pitting on guava slices surface.

\subsection{Colour measurement}

$\mathrm{L}^{*}$ value and $\mathrm{h}^{\circ}$ (hue angle) are the most precise values about colour changes in fresh-cut. The $\mathrm{L}^{*}$ value was used as an indicator of brightness, a point to chromaticity on a green (-) to red $(+)$ axis, $b^{*}$ indicate to yellow/blue rival colours with blue at negative $b^{*}$ values and yellow at positive $b^{*}$ values. Hue $\left(h^{\circ}\right)$ is the common correspondence between colours positioned around a colour wheel, chroma is the value of a colour's pureness, intensity or saturation (Nambi et al., 2015).

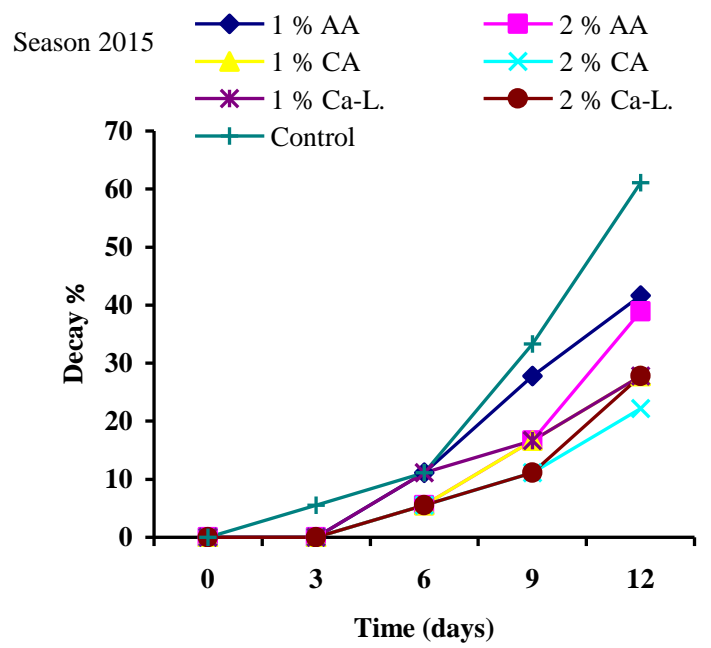

Fig. (1): Impact of ascorbic acid (AA), citric acid (CA) and calcium lactate (Ca-L) treatments on guava decay $(\%)$ in 2014,2015 seasons.

Agular et al. (2000) reported similar findings concerning anti-browning agents.

\subsection{General appearance}

Fig. (2) presents the effect of citric acid, ascorbic acid and calcium lactate treatments on fresh cut guava general appearance. Guava slices freshness decreased sharply during cold storage.
The results presented in Fig. (3) indicate that 1 and $2 \%$ citric acid treatments exhibited the highest significant values in the first season, whereas $2 \%$ citric acid showed the highest significant value in the second season compared with untreated ones which showed the lowest values in both seasons. 

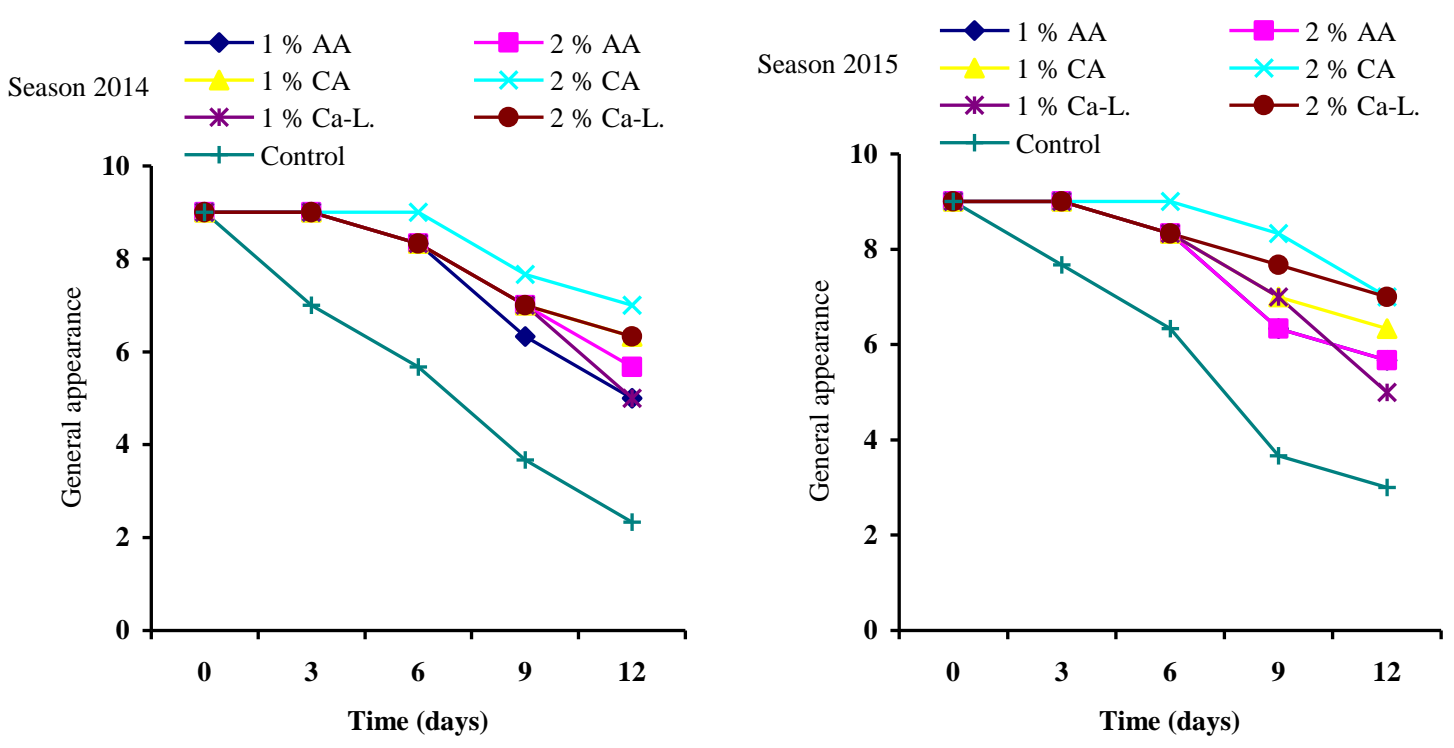

Fig. (2): Effect of ascorbic acid (AA), citric acid (CA) and calcium lactate (Ca-L) treatments on guava general appearance (general appearance was evaluated visually on a scale, $1=$ unacceptable, $3=$ poor, 5 = fair, 7 = good, and $9=$ excellent $)$ in 2014 , 2015 seasons.
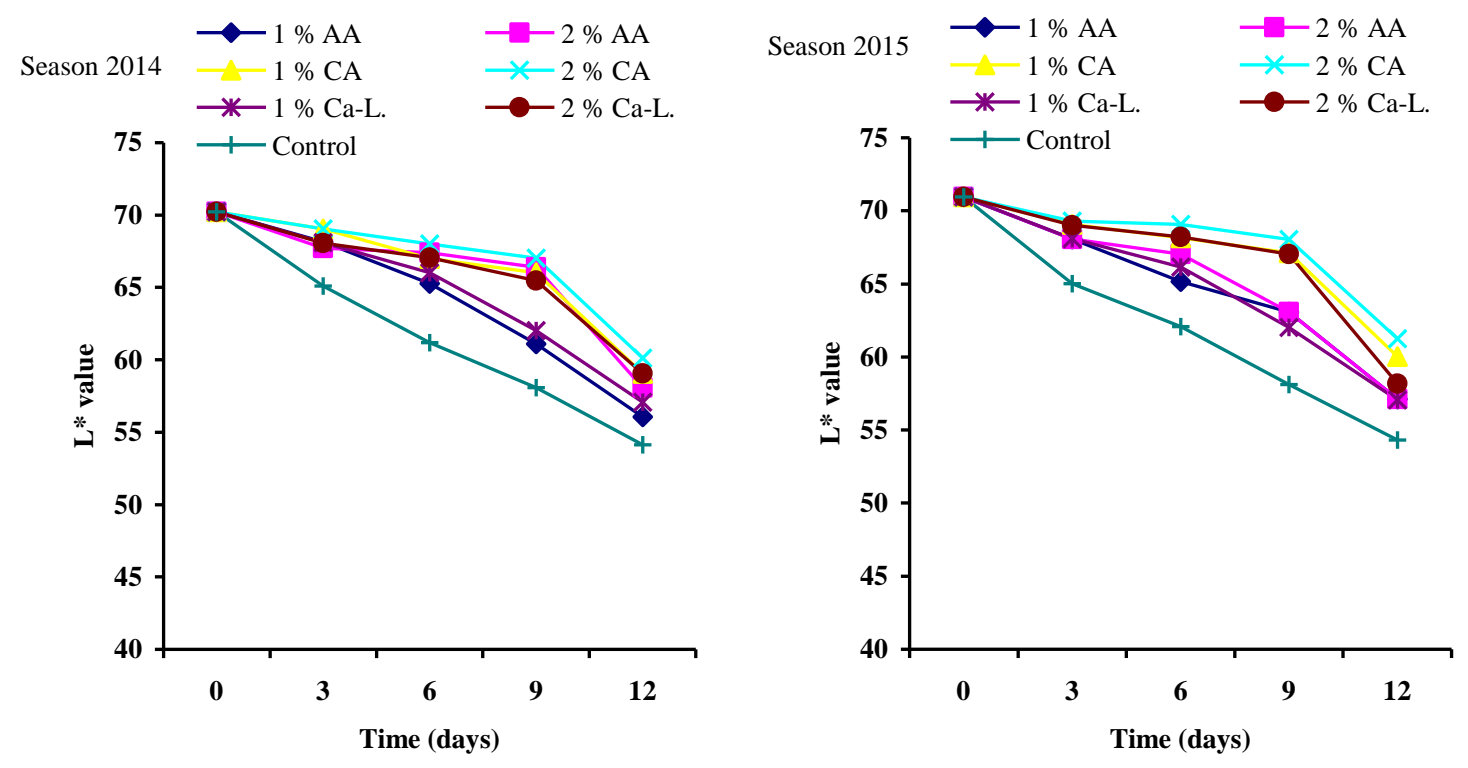

Fig. (3): Influence of ascorbic acid (AA), citric acid (CA) and calcium lactate (Ca-L) treatments on $\mathrm{L}^{*}$ value in 2014, 2015 seasons.

$L^{*}$ value decreased gradually during cold storage, where high concentration of citric acid showed the highest values after 12 days of storage at $5^{\circ} \mathrm{C}$ as it recorded 60.11 and 61.25 in 2014 and 2015 seasons, respectively, compared with untreated specimens that showed the least brightness values.

Findings illustrated in Table (1) show that citric acid at $2 \%$ recorded the highest significant $h$ values compared with the control in both seasons.

A gradual reduction in $\mathrm{h}^{\circ}$ values was observed during storage. Slices treated by 
Table (1): Effect of ascorbic acid (AA), citric acid (CA) and calcium lactate (Ca-L) treatments on $\mathbf{h}^{\circ}$ values of guava in 2014, 2015 seasons.

\begin{tabular}{|c|c|c|c|c|c|c|c|c|c|c|c|c|}
\hline \multirow{3}{*}{$\begin{array}{l}\text { Treatment } \\
\text { (T) }\end{array}$} & \multicolumn{6}{|c|}{ Days of storage at $5^{\circ} \mathrm{C}$ (D) } & \multicolumn{6}{|c|}{ Days of storage at $5^{\circ} \mathrm{C}$ (D) } \\
\hline & $\mathbf{0}$ & 3 & 6 & 9 & 12 & Mean & $\mathbf{0}$ & 3 & 6 & 9 & 12 & Mean \\
\hline & \multicolumn{6}{|c|}{ First season } & \multicolumn{6}{|c|}{ Second season } \\
\hline $1 \% \mathrm{AA}$ & 97.32 & 95.03 & 94.60 & 93.11 & 92.53 & 94.52 & 97.93 & 97.13 & 95.31 & 92.84 & 91.80 & 95.00 \\
\hline $2 \% \mathrm{AA}$ & 97.32 & 95.37 & 95.08 & 94.21 & 94.03 & 95.20 & 97.93 & 97.33 & 95.24 & 92.75 & 91.97 & 95.04 \\
\hline $1 \% \mathrm{CA}$ & 97.32 & 96.07 & 95.49 & 95.10 & 94.52 & 95.70 & 97.93 & 97.83 & 96.53 & 93.53 & 92.63 & 95.69 \\
\hline $2 \% \mathrm{CA}$ & 97.32 & 96.51 & 95.31 & 95.14 & 95.05 & 95.87 & 97.93 & 97.83 & 96.83 & 94.37 & 92.90 & 95.97 \\
\hline $1 \% \mathrm{Ca}-\mathrm{L}$. & 97.32 & 95.50 & 95.24 & 94.24 & 93.38 & 95.14 & 97.93 & 97.03 & 95.30 & 92.70 & 91.53 & 94.90 \\
\hline $2 \% \mathrm{Ca}-\mathrm{L}$. & 97.32 & 95.50 & 95.12 & 94.53 & 94.37 & 95.37 & 97.93 & 97.10 & 96.39 & 93.53 & 92.23 & 95.43 \\
\hline Control & 97.32 & 95.39 & 93.40 & 92.30 & 91.14 & 93.91 & 97.93 & 96.04 & 94.23 & 92.30 & 91.31 & 94.36 \\
\hline Mean & 97.32 & 95.62 & 94.89 & 94.09 & 93.58 & & 97.93 & 97.19 & 95.69 & 93.14 & 92.05 & \\
\hline L.S.D ${ }^{0.05}$ & \multicolumn{6}{|c|}{$(T)=0.67,(D)=0.56,(T \times D)=1.94$} & \multicolumn{6}{|c|}{$(T)=0.35,(D)=0.30,(T \times D)=0.79$} \\
\hline
\end{tabular}

different concentrations of citric acid kept the highest values until the end of the storage period at $5^{\circ} \mathrm{C}$ compared with the control, which showed the lowest standards in both seasons.

Decrement in lightness and $h^{\circ}$ values were possibly caused by an increase in the respiration rate and the promotion of enzymatic processes that were responsible for a decrease in quality that involved browning and other reactions (McGuire, 1992).

Although citric acid was more effective on colour preservation under this study conditions, Pizocaro et al. (1993) found that dipping fresh cut apple in ascorbic acid for 5 min. decreased browning (maintaining lightness) effectively compared with citric acid by decreasing oxidation.
Moreover, citric acid has been reported widely for its inhibitory activity on polyphenol oxidase, and its antibrowning role in fresh-cut fruits and vegetables (Rosen and Kader, 1989).

\subsection{Browning index}

Browning index is defined as brown colour purity, and it is considered one of the most common indicators of discolouration in sugar containing fruit products (Buera et al., 1986).

The results presented in Fig. (4) reveal that browning index increased gradually under all conditions. Untreated ones showed the highest significant indices in 2014 and 2015 seasons, while 2\% citric acid showed the lowest significant browning index in both seasons.

At the end of storage period in the first season, the control showed the highest
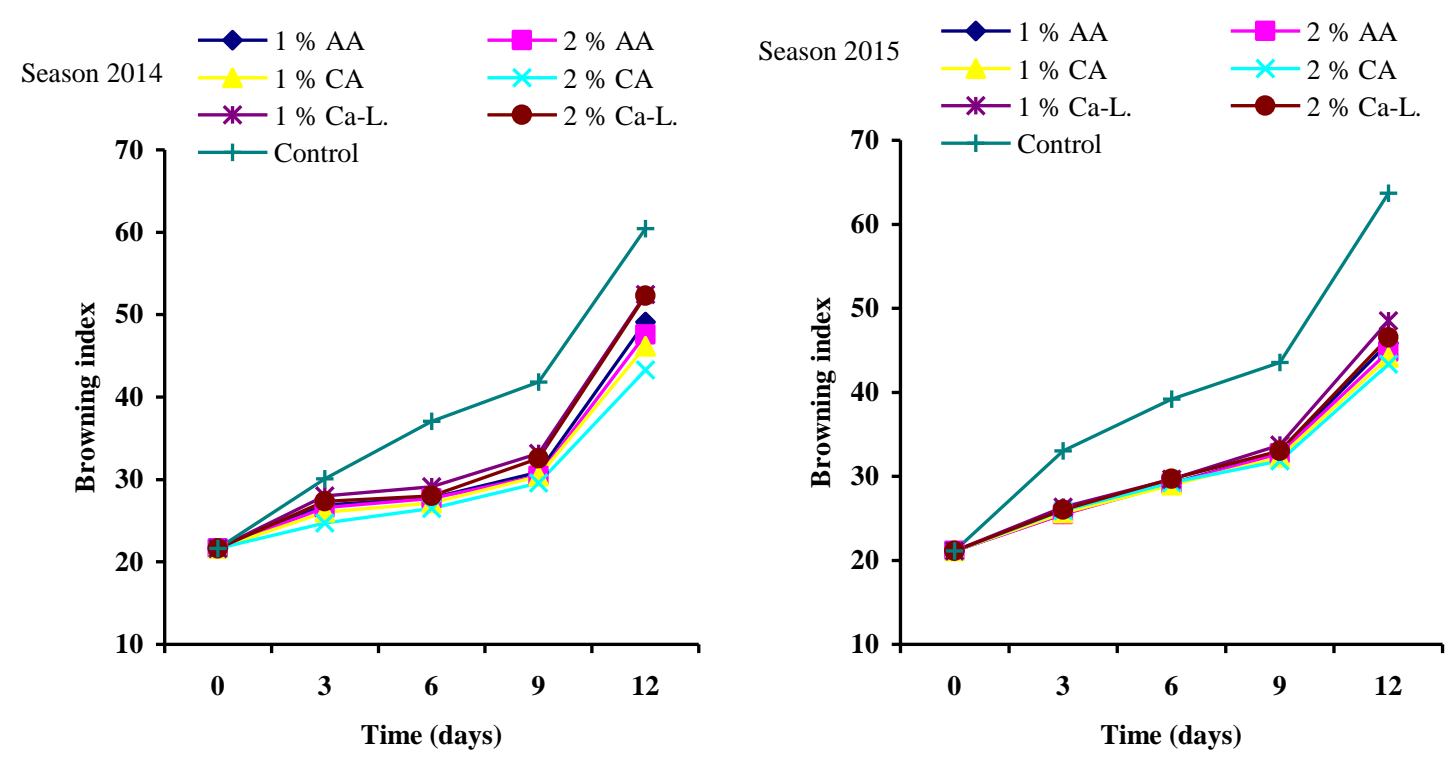

Fig. (4): Influence of ascorbic acid (AA), citric acid (CA) and calcium lactate (Ca-L) treatments on BI values in 2014, 2015 seasons. 
significant value of 60.46 , while $2 \%$ citric acid showed the lowest significant browning index of 43.29. Also, at the end of the storage period in the second season, the control showed the highest significant value of 63.72 , while citric at $2 \%$ acid showed the lowest significant value of 43.33. The antioxidant desired effect may be due to inhibition or reducing the enzymatic transformation of phenols to quinones, which slow down browning effectively (Lozano-DeGonzalez et al., 1993).

\subsection{Weight loss percentage}

Product weights are very important values that express the final biological changes result in fresh commodity and they have a big impact on commercial standards. Decrement of weight in fresh-cut fruits is lower compared with whole fruit during cold storage (Abd El-Moneim et al., 2015) because of airtight packages in the case of fresh-cut.

Table (2) indicates that, under all circumstances weight loss percentage increased gradually during storage periods. Calcium lactate at $2 \%$ showed the lowest significant weight loss percentages after 12 days of storage at $5^{\circ} \mathrm{C}$ compared with the control in both seasons.

In agreement with our findings Lamikrana and Watson (2007) found that application of calcium lactate depressed respiration and improved cell wall turgidity as it establish strong links between cell surfaces that may result in reduction of water loss rates. control after 12 days of storage at $5^{\circ} \mathrm{C}$ compared with the control, which showed the lowest values in both seasons.

Also, Coci et al. (2006) showed a structural breakdown with subsequent softening in apple tissue. Firmness reduction of slices occurs due to dissolution of middle lamella and cell separation as a result of the activity of pectin esterase, even at low temperature (Roccui et al., 2005).

Studied treatments with ascorbic and citric acid did not result in tissue softening, which were not agreeable to those reported by Gil et al. (1998).

Calcium lactate has been widely reported for its potential role in maintaining postharvest quality and decreasing softening by reducing the ripening processes along with reducing the deterioration (Pereira et al., 2009), Postharvest application of calcium lactate lowered respiration and increased firmness (Lamikrana and Watson, 2007), treatment of calcium may led to strong cell wall structure through the bond between calcium and pectin (Gorny et al., 2002).

Rodrigues et al. (2010) pointed out that the most obvious change in slices was a fast loss in firmness a few hours after processing, even at low temperatures, calcium lactate was effective in retaining firmness in most fresh-cut fruits.

The promising effect of calcium lactate could be due to maintaining the cell wall structure in fruit by interacting with pectins in the cell wall to form calcium pectate that supports molecular

Table (2): Effect of ascorbic acid (AA), citric acid (CA) and calcium lactate (Ca-L) treatments on guava weight loss $(\%)$ in 2014, 2015 seasons.

\begin{tabular}{|c|c|c|c|c|c|c|c|c|c|c|c|c|}
\hline \multirow{3}{*}{$\begin{array}{l}\text { Treatment } \\
\text { (T) }\end{array}$} & \multicolumn{6}{|c|}{ Days of storage at $5^{\circ} \mathrm{C}(\mathrm{D})$} & \multicolumn{6}{|c|}{ Days of storage at $5^{\circ} \mathrm{C}$ (D) } \\
\hline & $\mathbf{0}$ & 3 & 6 & 9 & 12 & Mean & $\mathbf{0}$ & 3 & 6 & 9 & 12 & Mean \\
\hline & \multicolumn{6}{|c|}{ First season } & \multicolumn{6}{|c|}{ Second season } \\
\hline $1 \% \mathrm{AA}$ & 0.000 & 0.151 & 0.311 & 0.442 & 0.773 & 0.335 & 0.000 & 0.085 & 0.205 & 0.336 & 0.694 & 0.264 \\
\hline $2 \% \mathrm{AA}$ & 0.000 & 0.187 & 0.329 & 0.478 & 0.800 & 0.359 & 0.000 & 0.176 & 0.346 & 0.528 & 0.727 & 0.355 \\
\hline $1 \% \mathrm{CA}$ & 0.000 & 0.106 & 0.282 & 0.331 & 0.493 & 0.242 & 0.000 & 0.112 & 0.192 & 0.358 & 0.412 & 0.215 \\
\hline $2 \% \mathrm{CA}$ & 0.000 & 0.177 & 0.216 & 0.346 & 0.463 & 0.241 & 0.000 & 0.225 & 0.291 & 0.425 & 0.491 & 0.286 \\
\hline $1 \% \mathrm{Ca}-\mathrm{L}$. & 0.000 & 0.161 & 0.239 & 0.267 & 0.450 & 0.223 & 0.000 & 0.159 & 0.192 & 0.263 & 0.374 & 0.198 \\
\hline $2 \%$ Ca-L. & 0.000 & 0.060 & 0.157 & 0.235 & 0.440 & 0.178 & 0.000 & 0.083 & 0.157 & 0.196 & 0.372 & 0.162 \\
\hline Control & 0.000 & 0.443 & 0.505 & 0.516 & 0.965 & 0.486 & 0.000 & 0.172 & 0.313 & 0.528 & 0.939 & 0.391 \\
\hline Mean & 0.000 & 0.184 & 0.291 & 0.373 & 0.626 & & 0.000 & 0.145 & 0.242 & 0.376 & 0.573 & \\
\hline L.S.D ${ }^{0.05}$ & \multicolumn{6}{|c|}{$(T)=0.007,(D)=0.006,(T \times D)=0.016$} & \multicolumn{6}{|c|}{$(\mathrm{T})=0.007,(\mathrm{D})=0.006,(\mathrm{~T} \times \mathrm{D})=0.016$} \\
\hline
\end{tabular}

\subsection{Firmness (Ib/inch $\left.{ }^{2}\right)$}

The results presented in Table (3) indicate that, there was a negative proportion between firmness and periods of storage in all treatments in both seasons.

Calcium lactate treatments showed the highest significant values compared with the bonding between constituents of cell wall (Degrave et al., 2003). Calcium also increases cell wall turgor pressure and stabilizes the membrane turgidity (Luna-Guzman and Barret, 2000). Also, the free carboxylic acid liberated by pectin methyl esterase can interact with calcium to form a molecular complex which results in an 
Table (3): Impact of ascorbic acid (AA), citric acid (CA) and calcium lactate (Ca-L) treatments on guava firmness $\left(\mathrm{lb} /\right.$ inch $\left.^{2}\right)$ in 2014, 2015 seasons.

\begin{tabular}{|c|c|c|c|c|c|c|c|c|c|c|c|c|}
\hline \multirow{3}{*}{$\begin{array}{c}\text { Treatment } \\
\text { (T) }\end{array}$} & \multicolumn{6}{|c|}{ Days of storage at $5^{\circ} \mathrm{C}(\mathrm{D})$} & \multicolumn{6}{|c|}{ Days of storage at $5^{\circ} \mathrm{C}$ (D) } \\
\hline & 0 & 3 & 6 & 9 & 12 & Mean & $\mathbf{0}$ & 3 & 6 & 9 & 12 & Mean \\
\hline & \multicolumn{6}{|c|}{ First season } & \multicolumn{6}{|c|}{ Second season } \\
\hline $1 \% \mathrm{AA}$ & 1.82 & 1.64 & 1.40 & 1.22 & 0.82 & 1.38 & 1.93 & 1.66 & 1.42 & 1.23 & 0.85 & 1.42 \\
\hline $2 \% \mathrm{AA}$ & 1.82 & 1.54 & 1.22 & 1.00 & 0.73 & 1.26 & 1.93 & 1.59 & 1.29 & 1.02 & 0.76 & 1.32 \\
\hline $1 \% \mathrm{CA}$ & 1.82 & 1.61 & 1.55 & 1.32 & 0.82 & 1.42 & 1.93 & 1.66 & 1.56 & 1.33 & 0.83 & 1.46 \\
\hline $2 \% \mathrm{CA}$ & 1.82 & 1.60 & 1.32 & 1.10 & 0.81 & 1.33 & 1.93 & 1.72 & 1.33 & 1.13 & 0.83 & 1.39 \\
\hline $1 \%$ Ca-L. & 1.82 & 1.71 & 1.50 & 1.42 & 1.02 & 1.49 & 1.93 & 1.76 & 1.51 & 1.45 & 1.05 & 1.54 \\
\hline $2 \% \mathrm{Ca}-\mathrm{L}$. & 1.82 & 1.71 & 1.60 & 1.41 & 1.11 & 1.53 & 1.93 & 1.79 & 1.61 & 1.41 & 1.13 & 1.58 \\
\hline Control & 1.82 & 1.20 & 0.90 & 0.80 & 0.55 & 1.05 & 1.93 & 1.25 & 0.92 & 0.86 & 0.65 & 1.12 \\
\hline Mean & 1.82 & 1.57 & 1.36 & 1.18 & 0.84 & & 1.93 & 1.63 & 1.38 & 1.20 & 0.87 & \\
\hline L.S.D $^{0.05}$ & \multicolumn{6}{|c|}{$(\mathrm{T})=0.06,(\mathrm{D})=0.05,(\mathrm{~T} \times \mathrm{D})=0.14$} & \multicolumn{6}{|c|}{$(\mathrm{T})=0.07,(\mathrm{D})=0.06,(\mathrm{~T} \times \mathrm{D})=0.15$} \\
\hline
\end{tabular}

enhancement of firmness (Degrave et al., 2003). Moreover, Robles-S'nchez et al. (2009) proved that the dipping fresh cut fruits in calcium lactate maintained the pectin methyl esterase and polygalacturonase activities during storage.

\subsection{TSS/Acid ratio}

Table (4) presents the influence of different concentrations of ascorbic acid, citric acid and calcium lactate on TSS/Acid ratio. Citric acid at $2 \%$ and $1 \%$ showed the highest significant ratios compared with the control in both seasons. Ratios of TSS/Acid increased regularly during cold storage but it decreased at the end of storage period. Both concentrations of citric acid maintained the highest ratios after 12 days of storage at $5^{\circ} \mathrm{C}$ compared with the control in both seasons.

In this regard, Gonzalez-Agular et al. (2000) reported considerable changes in fructose and glucose in fresh-cut mango treated with antibrowning means and stored at $10^{\circ} \mathrm{C}$.

The increase in total soluble solids/acid ratio could be attributed mainly to the decrease of acidity due to consumption of organic acids in fruits during respiration and biological changes of starch, soluble sugars, sucrose and glucose during ripening, but with storage prolongation total soluble solids decrease (Ahvenainen, 1996). 3.8. Total phenols (mg gallic acid/100g FW)

Table (5) presents the effect of different concentrations of calcium lactate, ascorbic acid and citric acid on total phenols content. Total phenols decreased continuously during cold storage prolongation. Citric acid at $2 \%$ showed the highest significant value compared with the control in the first season, whereas citric acid and ascorbic acid treatments showed the highest significant values compared with untreated ones in the second season.

Both citric acid concentrations and 1\% ascorbic acid treatments showed the highest values after 12 days of storage at $5^{\circ} \mathrm{C}$ compared with the control that showed the lowest content in both seasons.

Decrement of the total phenolic content with the prolongation of storage period is probably

Table (4): Effect of ascorbic acid (AA), citric acid (CA) and calcium lactate (Ca-L) treatments on TSS/Acid ratio of guava in 2014,2015 seasons.

\begin{tabular}{|c|c|c|c|c|c|c|c|c|c|c|c|c|}
\hline \multirow{3}{*}{$\begin{array}{l}\text { Treatment } \\
\text { (T) }\end{array}$} & \multicolumn{6}{|c|}{ Days of storage at $5^{\circ} \mathrm{C}$ (D) } & \multicolumn{6}{|c|}{ Days of storage at $5^{\circ} \mathrm{C}$ (D) } \\
\hline & $\mathbf{0}$ & 3 & 6 & 9 & 12 & Mean & $\mathbf{0}$ & 3 & 6 & 9 & 12 & Mean \\
\hline & \multicolumn{6}{|c|}{ First season } & \multicolumn{6}{|c|}{ Second season } \\
\hline $1 \% \mathrm{AA}$ & 8.83 & 9.89 & 10.14 & 11.51 & 12.13 & 10.50 & 8.53 & 9.59 & 10.04 & 11.37 & 11.82 & 10.27 \\
\hline $2 \% \mathrm{AA}$ & 8.83 & 9.93 & 10.24 & 11.65 & 12.24 & 10.58 & 8.53 & 9.74 & 10.09 & 11.36 & 11.82 & 10.31 \\
\hline $1 \% \mathrm{CA}$ & 8.83 & 10.04 & 10.25 & 12.26 & 13.04 & 10.88 & 8.53 & 9.85 & 10.18 & 11.59 & 12.44 & 10.52 \\
\hline $2 \% \mathrm{CA}$ & 8.83 & 10.15 & 10.70 & 12.63 & 13.39 & 11.14 & 8.53 & 9.89 & 10.25 & 11.92 & 12.71 & 10.66 \\
\hline $1 \% \mathrm{Ca}-\mathrm{L}$. & 8.83 & 9.93 & 10.14 & 11.52 & 12.16 & 10.51 & 8.53 & 9.81 & 10.03 & 11.32 & 11.66 & 10.27 \\
\hline $2 \% \mathrm{Ca}-\mathrm{L}$. & 8.83 & 9.97 & 10.44 & 12.00 & 12.79 & 10.81 & 8.53 & 9.52 & 9.78 & 11.39 & 11.84 & 10.21 \\
\hline Control & 8.83 & 9.85 & 9.95 & 11.40 & 11.97 & 10.40 & 8.53 & 9.22 & 9.63 & 10.48 & 10.91 & 9.75 \\
\hline Mean & 8.83 & 9.96 & 10.27 & 11.85 & 12.53 & & 8.53 & 9.66 & 10.00 & 11.35 & 11.89 & \\
\hline L.S.D ${ }^{0.05}$ & \multicolumn{6}{|c|}{$(T)=0.10,(D)=0.09,(T \times D)=0.23$} & \multicolumn{6}{|c|}{$(\mathrm{T})=0.14,(\mathrm{D})=0.12,(\mathrm{~T} \times \mathrm{D})=0.32$} \\
\hline
\end{tabular}


Table (5): Effect of ascorbic acid (AA), citric acid (CA) and calcium lactate (Ca-L) treatments on total phenols (mg gallic acid $/ 100 \mathrm{~g}$ FW) of guava in 2014,2015 seasons.

\begin{tabular}{|c|c|c|c|c|c|c|c|c|c|c|c|c|}
\hline \multirow{3}{*}{$\begin{array}{l}\text { Treatment } \\
\text { (T) }\end{array}$} & \multicolumn{6}{|c|}{ Days of storage at $5^{\circ} \mathrm{C}(\mathrm{D})$} & \multicolumn{6}{|c|}{ Days of storage at $5^{\circ} \mathrm{C}(\mathrm{D})$} \\
\hline & $\mathbf{0}$ & 3 & 6 & 9 & 12 & Mean & $\mathbf{0}$ & 3 & 6 & 9 & 12 & Mean \\
\hline & \multicolumn{6}{|c|}{ First season } & \multicolumn{6}{|c|}{ Second season } \\
\hline $1 \% \mathrm{AA}$ & 125.42 & 117.50 & 113.50 & 109.07 & 99.47 & 112.99 & 132.07 & 128.27 & 118.77 & 114.07 & 102.50 & 119.13 \\
\hline $2 \% \mathrm{AA}$ & 125.42 & 119.13 & 114.07 & 109.13 & 96.63 & 112.88 & 132.07 & 130.20 & 119.80 & 114.74 & 102.40 & 119.84 \\
\hline $1 \% \mathrm{CA}$ & 125.42 & 115.27 & 112.17 & 108.07 & 99.60 & 112.10 & 132.07 & 128.50 & 120.10 & 113.10 & 103.11 & 119.38 \\
\hline $2 \% \mathrm{CA}$ & 125.42 & 120.07 & 115.07 & 110.07 & 100.10 & 114.14 & 132.07 & 129.13 & 119.07 & 116.03 & 102.50 & 119.76 \\
\hline $1 \% \mathrm{Ca}-\mathrm{L}$. & 125.42 & 114.14 & 108.10 & 96.04 & 88.07 & 106.35 & 132.07 & 127.50 & 113.07 & 105.13 & 99.50 & 115.45 \\
\hline $2 \%$ Ca-L. & 125.42 & 116.17 & 108.43 & 96.13 & 88.07 & 106.84 & 132.07 & 128.03 & 110.07 & 103.03 & 99.80 & 114.60 \\
\hline Control & 125.42 & 110.13 & 94.04 & 89.40 & 80.17 & 99.83 & 132.07 & 115.03 & 100.03 & 90.07 & 82.07 & 103.85 \\
\hline Mean & 125.42 & 116.06 & 109.34 & 102.56 & 93.16 & & 132.07 & 126.67 & 114.41 & 108.03 & 98.84 & \\
\hline L.S.D ${ }^{0.05}$ & \multicolumn{6}{|c|}{$(\mathrm{T})=0.99,(\mathrm{D})=0.84,(\mathrm{~T} \times \mathrm{D})=2.23$} & \multicolumn{6}{|c|}{$(\mathrm{T})=0.72,(\mathrm{D})=0.61,(\mathrm{~T} \times \mathrm{D})=1.61$} \\
\hline
\end{tabular}

due to the oxidation by polyphenol oxidase (Yamaguchi et al., 2003). Also, quercetin is oxidized directly by polyphenol oxidase. Moreover, Robards et al. (1999) found that phenolic compounds have significant role in oxidation progressions as antioxidant substrates in browning reactions, leading to extend storage life. Their effects on the inhibition of oxidation of low density lipo proteins have been widely considered (Eberhardt et al., 2000). Rodrigues et al. (2010) illustrated that citric acid was more efficient than ascorbic acid and calcium lactate in maintaining or increasing the total phenol contents in the fresh-cut fruits. These findings are also in agreement with those obtained by Raheem et al. (2013), indicating to reduction of browning in treated fresh-cut slices.

\subsection{Ascorbic acid (mg/100g FW)}

Table (6) reveals that ascorbic acid decreased dramatically during storage. Citric acid at $2 \%$ showed the highest significant value after 12 days in the first season, whereas citric acid at $2 \%$ and ascorbic acid at $2 \%$ treatments showed the highest significant values in the second season compared with the control that showed the lowest values.

The reason for ascorbic acid losses during storage is oxidation that occurs spontaneously when the ascorbic acid is combined with oxygen in the air (Owusu-Yaw et al., 1988). Ascorbic acid is very unstable, this disintegrate is mainly due to the action of ascorbic acid oxidase and the reaction with oxygen, heavy metal ions and light (Bode et al., 1990); therefore, ascorbic acid is taken as an indicator of fruit freshness and retention of other constituents.

The obtained results are in line with those obtained by Pizocaro et al. (1993), who found that dipping the fresh cut fruits in ascorbic and citric acids solutions for $5 \mathrm{~min}$. had a varied impact on ascorbic acid content, polyphenol oxidase activity, discolouration and deterioration in fruits. In addition, Abd El-Moneim et al. (2015) declared that fresh-cut guava treated by citric acid at $2 \%$ exhibited significant less degradation of ascorbic acid content.

Table (6): Effect of ascorbic acid, citric acid and calcium lactate treatments on guava content of ascorbic acid $(\mathrm{mg} / 100 \mathrm{~g} \mathrm{FW})$ in 2014, 2015 seasons.

\begin{tabular}{|c|c|c|c|c|c|c|c|c|c|c|c|c|}
\hline \multirow{3}{*}{$\begin{array}{l}\text { Treatment } \\
\text { (T) }\end{array}$} & \multicolumn{6}{|c|}{ Days of storage at $5^{\circ} \mathrm{C}$ (D) } & \multicolumn{6}{|c|}{ Days of storage at $5^{\circ} \mathrm{C}(\mathrm{D})$} \\
\hline & 0 & 3 & 6 & 9 & 12 & Mean & 0 & 3 & 6 & 9 & 12 & Mean \\
\hline & \multicolumn{6}{|c|}{ First season } & \multicolumn{6}{|c|}{ Second season } \\
\hline $1 \% \mathrm{AA}$ & 94.68 & 94.13 & 86.84 & 84.67 & 79.66 & 88.00 & 95.39 & 95.41 & 89.11 & 82.87 & 79.87 & 88.53 \\
\hline $2 \% \mathrm{AA}$ & 94.68 & 94.55 & 87.20 & 83.17 & 79.49 & 87.82 & 95.39 & 95.42 & 91.75 & 84.64 & 79.30 & 89.30 \\
\hline $1 \% \mathrm{CA}$ & 94.68 & 94.11 & 85.02 & 81.27 & 79.35 & 86.89 & 95.39 & 95.56 & 88.43 & 84.52 & 79.56 & 88.69 \\
\hline $2 \% \mathrm{CA}$ & 94.68 & 94.20 & 92.38 & 85.05 & 79.97 & 89.25 & 95.39 & 95.53 & 89.69 & 84.60 & 80.13 & 89.07 \\
\hline $1 \% \mathrm{Ca}-\mathrm{L}$. & 94.68 & 93.93 & 86.58 & 79.46 & 77.46 & 86.42 & 95.39 & 94.88 & 87.80 & 82.21 & 79.21 & 87.90 \\
\hline $2 \%$ Ca-L. & 94.68 & 93.99 & 84.95 & 80.82 & 78.93 & 86.67 & 95.39 & 94.91 & 86.33 & 81.00 & 78.93 & 87.31 \\
\hline Control & 94.68 & 85.54 & 79.16 & 69.71 & 64.92 & 78.80 & 95.39 & 84.68 & 78.91 & 72.27 & 64.93 & 79.24 \\
\hline Mean & 94.68 & 92.92 & 86.02 & 80.59 & 77.11 & & 95.39 & 93.77 & 87.43 & 81.73 & 77.42 & \\
\hline L.S.D ${ }^{0.05}$ & \multicolumn{6}{|c|}{$(T)=0.92,(D)=0.78,(T \times D)=2.06$} & \multicolumn{6}{|c|}{$(T)=1.01,(D)=0.86,(T \times D)=2.26$} \\
\hline
\end{tabular}




\section{Conclusion}

The present work declared that citric acid, ascorbic acid and calcium lactate maintained the quality of guava pieces effectively for 9 days of storage at $5^{\circ} \mathrm{C}$. Citric acid at $2 \%$ treatment maintained the general appearance, total soluble solids/acid ratio, ascorbic acid and total phenols of fresh-cut guava, it also recorded the lowest colour changes and decay percentage. Ascorbic acid treatments showed significant impacts on fresh-cut guava content of the total phenols and ascorbic acid. Calcium lactate at $2 \%$ showed the lowest significant values of weight loss and the highest significant firmness compared with untreated ones. The obtained results clarified that it is possible to prolong the life of fresh cut guava by using anti-browning and supporting firmness treatments, whereas citric acid maintained the characteristics of quality effectively for 9 days and calcium lactate contributed to maintain the rigidity and weight without causing bitterness or bad appearance.

\section{REFERENCES}

A.O.A.C. (1980). Official methods of analysis $13^{\text {th }}$ ed. Association of official analytical chemists, Washington, D.C., USA.

A.O.A.C. (2012). Official methods of analysis $19^{\text {th }}$ ed. Guidelines for standard method performance requirements, Washington, D.C., USA.

Abd El-Moneim E. A., Kamel H. M., Zaki Z. A. and Abo Rehab M.E. (2015). Effect of honey and citric acid treatments on postharvest quality of fruits and fresh-cut of guava. World J. Agric. Sci. 11 (5): 255-267.

Ahvenainen R. (1996). New approaches in improving the shelf life of minimally processed fruit and vegetables. Trends in Food Sci. Tech., 7 (6):179-187.

Alley E.W., Nathanee P.K. and Donna A.M. (1996). Factors affecting quality of fresh-cut horticultural products. Postharvest Biol. Tech., 9: 115-125.

Amiot M. J., Tacchini M., Aubert S.Y. and Oleszek W. (1995). Influence of cultivar, maturity stage, and storage conditions on phenolic composition and enzymatic browning in pear fruits. J. Agric. Food Chem., 43: 1132-1137.

Bode A. M., Cunningham L. and Rose R.C. (1990). Spontaneous decay of oxidized ascorbic acid (dehydro-L-ascorbic acid) evaluated by high-pressure liquid chromatography. Am. Assoc. Clin. Chem.,
36:1807-1809.

Brown B.I. and Wills R.B. (1983). Postharvest changes in guava fruit with different maturity. Scientia Hort., 19:237-243.

Buera M.P., Lozano R.D. and Petriella C. (1986). Definition of colour in the non enzymatic browning process. Die. Farbe., 32, 318-322.

Coci P., Romani S. and Dalla Rosa M. (2006). Changes in Nutritional Properties of Minimally Processed Apples during Storage. Postharvest Biol. Tech., 39 (3): 265-271.

Degrave P., Saurel R. and Cautel Y. (2003). Vacuum impregnation pretreatment with pectin methyl esterase to improve firmness of pasteurized fruits. J. Food Sci., 68: 716 -721.

Drake S.R. and Spayed S.E. (1983). Influence of calcium treatment on golden delicious apple quality. J. Food Sci., 48 (2): 403-405.

Durigan J.F., Mattiuz B.H., Lima M.A. and Epiphanio R.D. (2005). Minimally processed guava fruits (Psidium guajava L.). Acta Hort., 682:1953-1960.

Eberhardt M., Lee C. and Liu R. (2000). Antioxidant activity of fresh apples. Nat., 405 (6789):903-904.

Fry S.C. (2004). Primary cell wall metabolism: tracking the carriers of wall polymers in living cells. New Phytol., 161:641-675.

Gil M., Aguayo E. and Kader A. A. (2006). Quality changes and nutrient retention in fresh-cut versus whole fruits during storage. J. Agric. Food Chem., 54:4284-4296.

Gil M., Gorny J.R. and Kader A. A. (1998). Responses of 'Fuji' Apple Slices to Ascorbic Acid Treatments and Low Oxygen Atmospheres. Hort. Sci., 33(2): 305-309.

Gonzalez-Agular A., Wang C. Y. and Buta J. C. (2000). Maintaining quality of fresh-cut mangoes using antibrowning agents and modified atmosphere packaging. J. Agric. Food Chem., 48 (9): 4204-4208.

Gorny J. R., Hess-Pierce B., Cifuentes R. A. and Kader A. A. (2002). Quality changes in freshcut pear slices as affected by controlled atmospheres and chemical preservatives. J. Postharvest Biol. Tech., 24:271-278.

Irene L. and Diane M. (2000). Comparison of calcium chloride and calcium lactate effectiveness in maintaining shelf stability and quality of fresh-cut cantaloupes. Postharvest Biol. Tech., 19:61-72.

Kader A. A. (1999). Fruit maturity, ripening, and quality relationships. Acta Hort., 485:203208.

Labuza T. P. and Schmidl M. K. (1988). Use of 
sensory data in the shelf-life testing of foods: principles and graphical methods of evaluation. Cereal Foods World, 33: 193-206.

Lamikrana O. and Watson M.A. (2007). Mild heat and calcium treatments effects on freshcut cantaloupe melon during storage. Food Chem., 102: 1383-1388.

Lozano-De-Gonzalez P.G., Barret D.M., Wrolstad R.E. and Durst R.W. (1993). Enzymatic browning inhibited in fresh and dried apple rings by pineapple juice. J. Food Sci., 58 (2): 399-403.

Luna-Guzman I. and Barret D. M. (2000). Comparison of calcium chloride and calcium lactate effectiveness in maintaining shelf stability and quality of fresh-cut cantaloupe. Postharvest Biol. Tech., 19: 61-72.

Martinez M.V. and Whitaker J.R. (1995). The biochemistry and control of enzymatic browning. Trends of Food Sci. Tech., 6: 195200.

Mazumdar B. C. and Majumder K. (2003). Methods on physicochemical analysis of fruits. Daya Publ. House, Delhi, India, 93139.

McGuire R. G. (1992). Reporting of objective color measurements. HortSci., 27:1254-1255.

Mitcham B., Cantwell M., and Kader A.A. (2003). Method for determining quality of fresh commodities. Pershiables Hand. Newslett., Issue No.85.

Nambi V. E., Thangavel K., Shahir S. and Geetha V. (2015). Evaluation of colour behavior during ripening of Banganapalli mango using CIE-Lab and RGB colour coordinates. J. Appl. Hort., 17 (3): 205-209.

Owusu-Yaw J., Marshall M., Koburger J. and Wei C. (1988). Low ph inactivation of pectin esterase in single strength orange juice. J. Food Sci., 53 (2): 504-507.

Patchimaporn U., Mahayothee B., Nagle M. and Muller J. (2014). Effects of calcium chloride and calcium lactate applications with osmotic pretreatment on physicochemical aspects and consumer acceptances of dried papaya. Int'l. J. Food Sci. Tech., 49: 1122-1131.

Pereira L.M., Carmello-Guerreiro S.M. and Hubinger M.D. (2009). Microscopic features, mechanical and thermal properties of osmotically dehydrated guavas. J. Food Sci. Tech., 42:378-384.

Pizocaro F., Torreggiani D. and Gilardi G. (1993). Inhibition of apple polyphenol oxidase by ascorbic acid, Citric Acid and Sodium Chloride. J. Food Proc. Preserv., 17
(1): 21-30.

Raheem M.I., Huma N., Anjum F. and Malik A. (2013). Effect of calcium chloride and calcium lactate on quality and shelf life of fresh-cut guava slices. Pak. J. Agri. Sci., 50 (3): 427-431.

Rosen J. and Kader A.A. (1989). Postharvest physiology and quality maintenance of sliced pear and strawberry fruits. J. Food Sci., 54 (3): 656-659.

Robards K., Penzle P.D., Tucker G., Swatsitang P. and Solver W. (1999). Phenolic compounds and their role in oxidative processed in fruits. Food Chem., 66 (4): 401-436.

Robles-S'anchez R.M., Islas-osuna M.A., Martin-Belloso S. and Gonzalez-Agular G.A. (2009). Quality index, consumer acceptability, bioactive compounds, and antioxidant activity of fresh-Cut "Ataulfo" mangoes (Mangifera Indica L.) as affected by low-temperature storage. J. Food Sci., 74 (3):126-134.

Roccui P., Romani S. and Rosa M.D. (2005). Effect of modified atmospheric packaging with argon and nitrous oxide on quality maintenance of minimally processed Kiwifruit. Postharvest Biol., Tech., 35:319- 328.

Rodrigues D.A., Miguel M.G., Cavaco A.M., Dandlen S., Nunes S. and Antunes M. (2010). Influence of citric acid, ascorbic acid and calcium lactate applications on the shelf life of minimally processed horticultural products. Acta Hort., 858: 369-372.

Ruangchakpet A. and Sajjaanantakul T. (2007). Effect of browning on total phenolic, flavonoid content and antioxidant activity in Indian Gooseberry (Phyllanthus emblica Linn.). Kasetsart J. (Nat. Sci.,) 41: 331-337.

Santerre C.R., Cash J.N. and Vannorman D.J. (1988). Ascorbic acid, citric acid combinations in the processing of frozen apple slices. J. Food Sci., 53 (6): 17131736.

Sams E. (1999). Preharvest Factors Affecting Postharvest Texture, Postharvest Biol. Tech., 15(3): 249-254.

Shah N.S. and Nath N. (2006). Minimally processed fruits and vegetables freshness with convenience. J. Food Sci. Tech., 43 (6): 561-570.

Sing S. P. and Pal R. K. (2008). Response of 
climacteric-type guava (Psidium guajava L.) to postharvest treatment with 1-MCP. J. Postharvest Biol. Tech., 47:307-314.

Snedecor G.W. and Cochran W.G. (1989). Statistical methods, $8^{\text {th }}$ Ed. lowa State Univ. press, Ames, lowa, USA.

Varela P., Salvador A. and Fiszman S.M. (2007). The use of calcium chloride in minimally processed apples. Eur. Food Res. Tech., 224 (4): 461-467.
Watada E. and Ling Q. (1999). Quality of freshcut produce. Postharvest Biol. Tech., 15 (3): 201-205.

Yamaguchi T., Katsuda M., Oda Y., Terao J., Kanazawa K. and Oshima S. (2003). Influence of polyphenoloxidase and ascorbate oxidase during cooking process on the radical scarning activity of vegetables. Food Sci. Tech. Res. 9 (1): 79 -83 .

\section{استخدام بعض المركبات المضادة للتلون البنى والداعمة للصلابة للحفاظ على جودة قطع الجوافة الطازجة عماد الدين حمدى خضر- مروة رشاد على}

قسم بساتين الفاكهة و* قسم علوم الاغذية ـ كلية الزر اعة ـ جامعة القاهرة- مصر

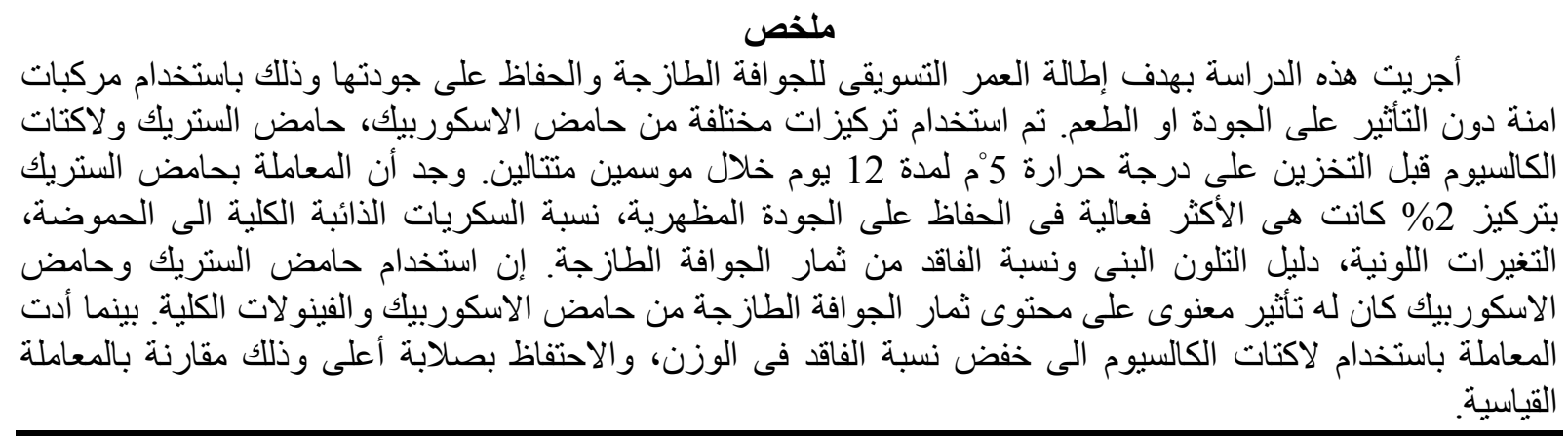
المجلة العلمية لكلية الزراعة - جامعة القاهرة - المجلد (68) العدد الثالث (يوليو 2017): 293-303. 